[Livingstone, I. (2009). Editorial: Ecologically Speaking. New Zealand Annual Review of Education, 18, 1-4]

\section{Editorial: Ecologically Speaking}

\section{IAN LIVINGSTONE}

$\mathrm{W}$ hat are we doing to our planet? How can we engender a sense of caring for "our place" in our children and grandchildren and great-grandchildren, who will inhabit the planet after we are gone? How expensive in ecological terms is the explosion of knowledge, in both hard copy and electronic form? What is the impact on the environment of the thousands of books, annual reports, monthlies, weeklies, dailies, not to mention the ever-growing plethora of ephemeral advertising materials which clutter up the mailboxes of everyone who decides against putting "No Junk Mail" stickers on the outside? How much of it is actually read? And how life-changing is what is read and absorbed? To bring it down to a more telling, personal level, how many trees have been felled to produce around 600 copies of this Annual Review of Education, averaging 300 pages each year over the past 19 years of its existence? And now that the Review is freely available on the internet, what impact is this likely to have on our ecological carbon footprint? In a recent Listener article, Sarah Barnett notes:

It's tempting to think of the web as a benign, tree-saving entity, but it's becoming apparent that's not necessarily the case. The New Scientist reported last month that it takes 152 billion kilowatthours per year "just to power the data centres that keep the net running" - that's enough electricity to keep New Zealand running for nearly four years. Taken together with the energy to power all the computers accessing it, the magazine estimated the net's footprint could account for as much as $2 \%$ of global emissions - around the same as the airline industry. And it's growing at the rate of $50 \%$ every year.

So maybe the extensive use of ICT is a less sensitive way of expanding our knowledge base than meets the eye. Few print outlets have calculated their carbon footprints, apparently, but there is some suggestion that a European reader of printed newspapers is responsible for a smaller emission of $\mathrm{CO}_{2}$ than one who spends half-an-hour browsing it on-line per day. ${ }^{1}$ Nevertheless, at the risk of adding to the
2 Ian Livingstone

problem, I can only trust that the following ten articles in my final issue as editor are important enough to justify their existence, as they are released to the world in hard copy and subsequently on the internet,

We begin with two articles which pick up this ecological thread as it relates to the education landscape. In the first, Professor Wally Penetito, Co-Director of He Parekereke, in the School of Educational Policy and Implementation, Victoria University of Wellington, notes that place-based education (PBE) is not an overly familiar term in the New Zealand education context, but it has a rapidly developing profile within the United States and parts of Canada, mainly as an outreach of the environmentalist movement. At the practical level "place-based education" sets out to answer two fundamental questions: "What is this place?" and "What is our relationship with it?" Wally uses the Māori powhiri with its pepiha as a fascinating illustration of the way in which the importance of "place" can be highlighted in the New Zealand education system. The article goes on to explore some of the theories and practices embedded in a place-based education for Aotearoa New Zealand and recommends a set of principles for advancing the practice.

In the second such article, Richard Fisher, a course leader in the Natural Resources Centre at the Open Polytechnic of New Zealand, based in Lower Hutt, agues for a clear distinction between traditional distance education and e-learning, on the basis of: geographical separation of "place" between teachers and students; lack of online access requirements; and the long-standing historical rationale for distance education in this country. The ecological concern is followed through in his use of Education for Sustainability (EFS) as a cautionary case study to illustrate the ways in which e-learning may not adequately serve the goals of EFS as well as traditional distance education.

In our third article, Richard James, Director of the Centre for the Study of Higher Education and a Professor of Higher Education at the University of Melbourne, analyses the challenges involved in transforming the Australian higher education system to achieve universal participation, in view of the ambitious goals of the 2008 Review of Australian Higher Education. Springing out of a keynote address given at the December 2008 annual conference of the New Zealand Association for Research in Education (NZARE), the article documents current patterns of educational disadvantage, and the underlying causes for the persistent under-representation in universities of certain groups of Australians. It moves on to propose a set of conditions needed for universal participation, and outlines the obstacles to embedding these in national and institutional policy and practice. While the analysis is framed within the present Australian political and 
social context, the conclusions are likely to be relevant for other national systems making the transition from mass to universal higher education.

Next, Noeline Alcorn, emeritus Professor of Education at the University of Waikato, argues that educational researchers need to create a robust public debate about what constitutes quality in educational research. Her article outlines the methodology used within the Performance-Based Research Fund (PBRF), in particular with regard to its Education Sector ratings, which have historically been low, and goes on to discuss ways of raising achievement and increasing capacity. A major concern is to enhance the status of applied or practice-based research and to foster discussion of appropriate ways to evaluate and assess its impact and ethical basis, without losing sight of the need for clarity and rigour.

In the first of two articles on teacher education, Linda Hogg, a lecturer in the School of Educational Psychology and Pedagogy in the Faculty of Education, Victoria University of Wellington, notes the need for prospective Pakeha teachers to transcend monocultural life experiences, to support their development as effective multicultural educators. Her article reviews three selected training strategies: teaching experience, case method, and interactive performance, in relation to their potential in addressing the issue, and outlines implications for teacher training institutions. In the following article, Roseanna Bourke, Director of the Centre for Educational Development for teacher professional learning, research and practice, in the College of Education at Massey University, Palmerston North joins with John O'Neill, also at Massey, in the School of Arts, Development and Health Education, in considering the use of a professional development programme to raise awareness of the New Zealand Teachers Council Code of Ethics for Registered Teachers. Their article illustrates how working through a range of carefully constructed, authentic, polarising real-life scenarios allows teachers to learn to challenge their own assumptions, values and beliefs safely and rationally.

In another jointly-written article, Claire Davison and Linda Mitchell, lecturer and senior lecturer, respectively, at the University of Waikato, analyse changing models of state responsibility for New Zealand kindergartens over recent years, and trace their repercussions on kindergartens and the wider early childhood education sector. They argue that the state needs to take a supportive and responsible role in provision of early childhood care and education, to support a move away from a market model, and to resolve inequities in children's access and teacher employment conditions that continue to beset the sector. The article ends by setting the discussion within an international context and suggests policy challenges for early childhood education in New Zealand. The second article continues the international slant, and is written by Brenda Bushouse, an Associate Professor of Political Science and Public Policy at the University of Massachusetts. From February to July 2008 she participated in the Ian Axford (New Zealand) Fellowship in Public Policy and was hosted by the Ministry of Education to study New Zealand early childhood policies. Her article provides a comparative perspective on early childhood education (ECE) policy in the USA and New Zealand. The contrast between the two countries is significant. In the USA the federal government funds early childhood education only for the poor and disabled. By way of contrast, the New Zealand 20 Hours Free programme initiated in 2007 provides 20 hours of free ECE for three- and four-year olds regardless of family income. This article discusses the creation of the programme, starting with its genesis in 2005, and considers what are regarded as "wedge" issues; the controversy over the exclusion of private services and parent/whanau-led services, and the ongoing debate over the restriction on "top-up" fees.

Tom Nicholson, Co-Director of the Centre of Excellence for Research on Children's Literacy (CERCL) at Massey University, Auckland, maintains that one of the biggest challenges in this country is to raise Māori achievement in literacy. Māori are the first nation, and it seems unjust that their literacy levels are not on a par with those of Pakeha despite massive efforts to close this gap. He argues that Māori children in New Zealand fail to receive a "fair deal" in learning to read for a number of reasons, but primarily because our schools employ inadequate methods of teaching reading. He tackles head-on the knotty issue of whole book methods versus phonics, and makes some practical suggestions about how these two approaches can be accommodated.

Finally, Trish McMenamin, a lecturer in the School of Educational Studies and Human Development at Canterbury University, considers Special Education 2000, the policy introduced in 1996 which was to herald a new era of resourcing and organisation for special education by fostering and developing an inclusive education system in New Zealand. In exploring its impact on New Zealand day-special schools. she suggests that an unintended consequence of the implementation of Special Education 2000 was that day-special schools experienced a period of significant growth and expansion. The effects of this growth on the schools and their communities are discussed, and the future role of day-special schools in an "inclusive" policy environment is considered.

Notes

1. Barnett, S. (2009, June 6). How green is my internet? Listener, p. 55. 